\title{
Corpus luteum maintenance during early pregnancy in the cow
}

\author{
Janina Lukaszewska* and W. Hansel
}

Physiology and Physical Biology, Cornell University, Ithaca, New York 14853, U.S.A.

\begin{abstract}
Summary. Holstein heifers (18 pregnant, 12 inseminated but non-pregnant, and 17 cyclic) were studied during the first 18 days after oestrus. Jugular vein plasma progesterone concentrations were significantly $(P<0.05)$ higher in pregnant than in non-pregnant and cyclic animals between Days 10 and 18. Jugular oestradiol concentrations were also higher in pregnant than in cyclic animals between Days 6 and $16(P<0.05)$. No differences were found among the three groups in jugular $\mathrm{LH}$ levels during Days 1-18. Ovarian and uterine vein progesterone and oestradiol concentrations suggested that the elevated peripheral plasma concentrations of these steroids in pregnant animals were due mainly to increased ovarian production, but the embryo itself may have contributed to the oestradiol levels found at Day 17. Luteal tissues from pregnant animals contained more progesterone when incubated alone or with LH than tissues from cyclic animals $(P<0.06)$. However, LH-stimulated synthesis (incubated with LH minus incubated alone) was nearly identical for the three groups of tissues. Therefore, loss of responsiveness to LH does not appear to be the initial event in luteolysis. Concentrations of PGF in ovarian arterial plasma in cyclic and pregnant animals were similar at Day 18, although uterine vein concentrations were higher $(P<0.05)$ in the cyclic animals. Free arachidonic acid concentrations in corpora lutea at Day 18 were higher $(P<0.05)$ in cyclic than in pregnant animals. The data suggest that the embryo may produce one or more luteotrophic substances that stimulate increased progesterone secretion by the corpus luteum, beginning as early as Day 10 of pregnancy.
\end{abstract}

\section{Introduction}

Little is known of the mechanism(s) by which the presence of an embryo in the uterus causes corpus luteum maintenance during early pregnancy in the cow. Plasma progesterone concentrations decline in the cyclic cow at Days 17-18 (Hansel \& Echternkamp, 1972) and luteal tissue is reported to lose the ability to respond to LH (luteinizing hormone) added in vitro at about Day 17 (Armstrong \& Black, 1966). The embryo therefore appears to signal its presence and cause corpus luteum maintenance at Day 17 or 18 . Whether this is accomplished by a direct luteotrophic mechanism of fetal origin, by inactivation of a luteolytic mechanism, or both, remains to be determined. Kindahl, Edqvist, Bane \& Granström (1976) suggested that pregnancy in the cow may be maintained by inhibition of luteolysis. Luteolysis in the cyclic cow is often assumed to be due to a local luteolytic action of prostaglandin (PG) F-2 $\alpha$ of uterine origin. However, Hansel \& Fortune (1977) summarized evidence suggesting that additional mechanisms may be involved. In order to provide further information on this problem, we have Poland.

- Present address: Child Health Centre/Memorial Hospital, Al. Dzieci Polskich 20,04-736 Warszawa-Miedzyleise, 
carried out experiments with 47 Holstein heifers, in which we have compared various features of the presumed luteolytic mechanism(s) in pregnant and non-pregnant animals at Days 17 and 18 and have looked for evidence of a fetal luteotrophic mechanism.

\section{Materials and Methods}

\section{Animals}

Holstein heifers were treated as follows: Group 1 contained 17 untreated cyclic controls; Group 2 contained 18 inseminated and pregnant animals; and Group 3 contained 12 heifers that were inseminated but had no embryos at Day 17 or 18. Daily jugular blood samples were taken at 08:00 h from Day 0 (oestrus) until Day 16, when samples were collected at 6-h intervals until Day 17 or 18 . Checks for oestrus were made twice daily and animals were considered in oestrus if they stood when mounted by others. Plasma samples were analysed for LH, progesterone, and oestradiol-17 $\beta$. At Day 17 or 18 all animals were subjected to mid-ventral laparotomy and the following procedures were carried out in the order listed: (1) ovarian arterial blood, uterine venous blood, and ovarian venous blood samples were collected; (2) the corpus luteum was removed; (3) the uterine horn ipsilateral to the corpus luteum was removed and flushed to remove the embryo, if present; and (4) a sample of endometrium was removed and frozen immediately on solid $\mathrm{CO}_{2}$. The plasma samples were analysed for progesterone, oestradiol, $\mathrm{LH}$, arachidonic acid and PGF. The corpora lutea were sliced and incubated for $2 \mathrm{~h}$ in the presence or absence of $\mathrm{LH}(3 \mu \mathrm{g})$ and arachidonic acid $(30 \mu \mathrm{g})$, as previously described by Hansel (1971). At the end of incubation, tissue and medium were frozen and saved for later measurements of progesterone, PGF, testosterone and oestradiol content. In addition, a small portion of each corpus luteum was analysed for lipoprotein lipase. The samples of endometria were analysed for PGF. Arachidonic acid measurements were made on plasma samples, corpora lutea and endometria of animals in Groups 1 and 2. The embryos and flushing media were frozen and stored for later use in other studies.

\section{Assays}

Hormones. Methods for determining LH, progesterone, oestradiol, testosterone, PGF and lipoprotein lipase were as previously described (Niswender, Reichert, Midgley \& Nalbandov, 1969; Jaffe, Behrman \& Parker, 1973; Shemesh, Bensadoun \& Hansel, 1976; Fortune \& Eppig, 1979), with the following modifications. Radioimmunoassays (RIA) of oestradiol and testosterone were performed on diethyl ether extracts of tissue homogenates or plasma. The extracts were first purified on Celite columns as described by Abraham, Tulchinsky \& Korenman (1970), except that propylene glycol was substituted for ethylene glycol as the stationary phase. Small quantities of radiolabelled hormone tracers were added to these samples to estimate losses during column chromatography. Samples assayed for progesterone were extracted with petroleum ether. In the PGF assay, the charcoal concentration was increased from 2.5 to $3.0 \mathrm{mg} / \mathrm{ml}$ and the dextran from 0.25 to $0.30 \mathrm{mg} / \mathrm{ml}$. The antibody used cross-reacted to a limited extent with PGF-1 $\alpha$ and 6-keto-PGF-1 $\alpha(0.04 \%)$ and the chromatographic procedure did not separate PGF-2 $\alpha$ from 6-keto-PGF-1 $\alpha$. Therefore, the data are expressed as PGF values. The performance specifications for the various RIAs are shown in Table 1. With the exception of the high inter-assay coefficient of variation for testosterone, all of these assay characteristics were satisfactory.

Arachidonic acid. As outlined by Folch, Lees \& Sloane-Stanley (1957), a total lipid extraction of homogenized tissue was employed. The extract was then separated into phospholipid, triglyceride, cholesterol ester and free fatty acid fractions by a thin-layer chromatography system described by Freeman \& West (1966), in which the developing solvent 
was hexane:diethyl ether:acetic acid (75:25:1 by vol.). Chloroform:methanol $(4: 1 \mathrm{v} / \mathrm{v})$ was used to elute all fractions, except phospholipids, for which chloroform :methanol $(1: 9 \mathrm{v} / \mathrm{v})$ was employed. Each eluate was esterified according to the method of Metcalfe, Schmitz \& Pelka (1966). Each fraction was further purified and measured with a Hewlett-Packard gas-liquid chromatograph equipped with a flame ionization detector and glass columns packed with $3 \%$ OV-225 on Gas-Chrom Q.

Table 1. Characteristics of radioimmunoassays

\begin{tabular}{lccc}
\hline & & \multicolumn{2}{c}{ Coefficient of variation } \\
\cline { 3 - 4 } & $\begin{array}{c}\text { Sensitivity } \\
(\mathrm{pg} / \text { tube })\end{array}$ & $\begin{array}{c}\text { Intra-assay } \\
(\%)\end{array}$ & $\begin{array}{c}\text { Inter-assay } \\
(\%)\end{array}$ \\
\hline Progesterone & 10 & 8.4 & 16.5 \\
Oestradiol-17 & 1.8 & 7.2 & 19.0 \\
PGF & 5.0 & 10.3 & 14.8 \\
Testosterone & 5.0 & 6.6 & 43.0 \\
LH & 50 & 10.9 & 22.0 \\
\hline
\end{tabular}

Lipoprotein lipase. The enzyme solution was obtained by extracting $100 \mathrm{mg}$ samples of acetone-ether powders of the homogenized luteal tissue with buffered saline. Lipoprotein lipase was determined in duplicate samples in two different incubations using a synthetic $\left[{ }^{14} \mathrm{C}\right]$ triolein substrate labelled in the oleic acid moiety, as described by Shemesh et al. (1976).

\section{Statistical tests}

These included analysis of variance and comparisons by Student's $t$ test.

\section{Results}

\section{Peripheral plasma hormones}

Progesterone. Jugular concentrations are shown in Text-fig. 1(a) and were higher $(P<0.05)$ in animals in Group 2 than in those of Groups 1 and 3 at all times between Days 10 and 18. Concentrations continued to rise in a linear fashion during the entire 18-day period in the pregnant animals, but a decline was noted in most non-pregnant animals by Day 18 . There were no significant differences between values for Groups 1 and 3 . The plasma progesterone concentrations in samples collected at 6-h intervals between Days 16 and 18 (data not shown) were all significantly $(P<0.05)$ higher in Group 2 heifers than in those in Groups 1 and 3.

Oestradiol. As shown in Text-fig. 1(b), oestradiol concentrations rose in all groups between Days 2 and 5. Values remained higher in Group 2 than in Group $1(P<0.01)$ during Days 6-16; while values for Group 3 animals were similar to those for Group 2 until Day 6 and then became intermediate between those of Groups 1 and 2. On Days 17 and 18, as the corpora lutea of the animals in Groups 1 and 3 began to regress, oestradiol concentrations began to rise and were similar to those found in pregnant animals (Group 2).

$L H$. No significant differences were seen in plasma LH concentrations among the three groups, although the levels in Group 3 were elevated at Days 3 and 4 (see Text-fig. 1c).

\section{Tissue concentrations}

Progesterone. As the experiment progressed, it became evident that, contrary to our expectations, the corpora lutea from Group 1 (cyclic) animals at Day 17 retained their ability to produce progesterone and to respond to added $\mathrm{LH}$ with relatively large increases in progesterone 

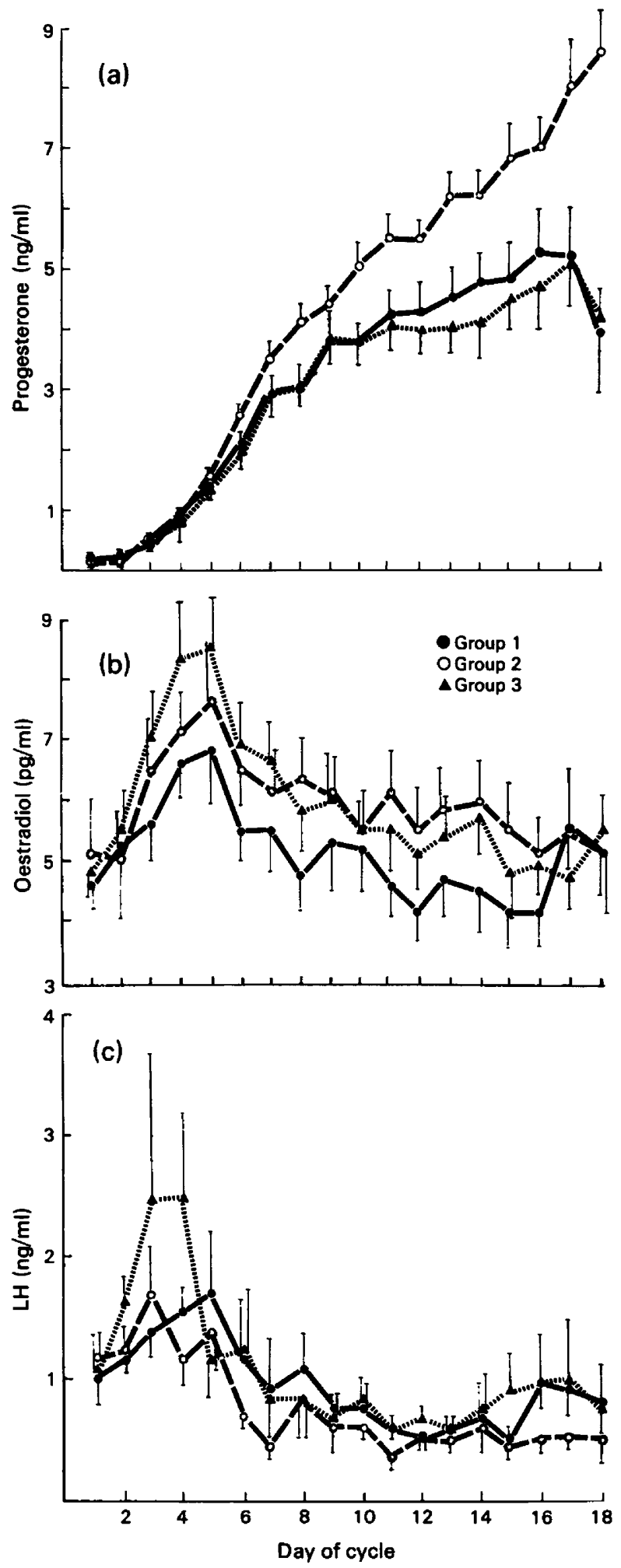

Text-fig. 1. Jugular venous plasma concentrations of (a) progesterone, (b)oestradiol-17 $\beta$ and (c) LH in 17 cyclic non-pregnant (

$($ (A, Group 1), 18 pregnant (O-- - 0 , Group 2 ) and 12 inseminated but s.e.m. 
synthesis. Consequently, after using 19 Day-17 animals (7 in Group 1, 8 in Group 2, and 4 in Group 3), the experiment was completed with Day-18 animals only and the data in Tables 2-5 relate only to animals for which embryo, tissue and blood collections were made on Day 18. However, data from Day-17 animals are cited when appropriate and complete data for these animals are available upon request.

Ovarian vein progesterone concentrations (Table 2), although highly variable, were many times higher than jugular vein concentrations $(P<0.01)$. Uterine vein plasma from Group 1 and 2 animals also contained higher progesterone concentrations than did jugular vein plasma $(P<$ 0.05 ). Ovarian vein concentrations were higher in Group 2 heifers than those of Groups 1 and 3 $(P<0.06)$. Ovarian arterial progesterone concentrations were highly variable and did not differ among the three groups at Day 17 or 18.

Table 2. Mean \pm s.e.m. progesterone concentrations in plasma and luteal tissue at Day 18 in pregnant and non-pregnant Holstein heifers

\begin{tabular}{|c|c|c|c|}
\hline & $\begin{array}{l}\text { Group } 1 \\
\text { (cyclic) }\end{array}$ & $\begin{array}{c}\text { Group } 2 \\
\text { (pregnant) }\end{array}$ & $\begin{array}{c}\text { Group } 3 \\
\text { (inseminated but } \\
\text { non-pregnant) }\end{array}$ \\
\hline No. of animals & 10 & 10 & 8 \\
\hline \multicolumn{4}{|l|}{ Plasma } \\
\hline Jugular vein $(\mathrm{ng} / \mathrm{ml})$ & $2.9 \pm 0.5$ & $5.3 \pm 0.9^{*}$ & $3.6 \pm 0.9$ \\
\hline Ovarian vein $(\mathrm{ng} / \mathrm{mi})$ & $383.5 \pm 200.4 \dagger$ & $1074 \cdot 6 \pm 272 \cdot 0 \dagger \ddagger$ & $376.5 \pm 97.1 \dagger$ \\
\hline Ovarian artery $(\mathrm{ng} / \mathrm{ml})$ & $54.0 \pm 21 \cdot 2$ & $44.2 \pm 30.4$ & $48.8 \pm 31.2$ \\
\hline Uterine vein $(\mathrm{ng} / \mathrm{ml})$ & $10.0 \pm 2.5 \dagger$ & $16.5 \pm 5.4 \dagger$ & $37 \cdot 0 \pm 20 \cdot 1$ \\
\hline \multicolumn{4}{|l|}{ Corpus luteum } \\
\hline Weight (g) & $4 \cdot 1 \pm 0.4$ & $5.1 \pm 0.3 \S$ & $3.9 \pm 0.3$ \\
\hline Unincubated $(\mu \mathrm{g} / \mathrm{g})$ & $27.2 \pm 5.8$ & $48.9 \pm 8.6^{*}$ & $38 \cdot 1 \pm 5 \cdot 8$ \\
\hline Incubated $(\mu \mathrm{g} / \mathrm{g})$ & $32.2 \pm 5.9$ & $66 \cdot 5 \pm 9 \cdot 3^{*}$ & $51.5 \pm 6.5^{*}$ \\
\hline Incubated with LH $(\mu \mathrm{g} / \mathrm{g})$ & $45 \cdot 2 \pm 7 \cdot 1$ & $81.1 \pm 8.4^{*}$ & $66.4 \pm 8.7$ \\
\hline $\begin{array}{l}\text { Incubated with arachidonic acid } \\
(\mu \mathrm{g} / \mathrm{g})\end{array}$ & $33.9 \pm 5.7$ & $66 \cdot 3 \pm 9 \cdot 4^{*}$ & $52 \cdot 0 \pm 5 \cdot 2^{*}$ \\
\hline Total progesterone $(\mu \mathrm{g} / \mathrm{g})$ & $117 \cdot 7 \pm 27 \cdot 9$ & $233 \cdot 2 \pm 30 \cdot 2 \ddagger$ & $151.7 \pm 29.8$ \\
\hline
\end{tabular}

* Values differ from those for Group $1, P<0.05$.

$\dagger$ Values differ from those in the jugular vein, $P<0.05$.

$¥$ Values differ from those in Groups 1 and $3, P<0.06$.

$\S$ Value differs from that of Groups 1 and 3 combined, $P<0.05$.

Corpus luteum weights were higher in pregnant than in non-pregnant animals $(P<0.05$ for combined data of Groups 1 and 3). At Day 18, luteal tissue progesterone concentrations were higher $(P<0.06)$ in unincubated tissue of Group 2 than Group 1 animals $(P<0.05)$. Total progesterone concentration was also highest in Group 2 animals. Progesterone concentration (tissue plus medium) was greater $(P<0.05)$ for Group 2 than for Group 1 animals when corpora lutea were incubated alone, incubated with LH or incubated with arachidonic acid (Table 2). However, the amounts of progesterone synthesized in response to added LH (obtained by subtracting the value for tissue incubated alone from that for tissue incubated with $\mathrm{LH}$ ) were nearly identical for the three groups $(14.6 \pm 3.2,17.5 \pm 4.5$ and $13.0 \pm 4.2 \mu \mathrm{g} / \mathrm{g})$. For Group 1 animals, corpus luteum weights and jugular plasma progesterone concentrations found at the time the corpora lutea were removed were highly correlated $(r=0.82, P<0.01)$. Progesterone synthesis by tissues incubated alone and incubated with LH wete also correlated for these animals $(r=0.85, P<0.01)$.

Most of the characteristics of luteal tissue from Group 3 animals were intermediate between those of luteal tissue from animals in Groups 1 and 2 (Table 2). Moreover, progesterone synthesis in these tissues, when incubated alone or incubated with $\mathrm{LH}$, was about equal to that for tissues of Group 2 and higher than in tissues of Group $1(P<0.05)$. 
Testosterone. These concentrations in luteal tissues were not different among the three groups at Day 17 or 18. Mean \pm s.e.m. concentrations for unincubated luteal tissue at Day 18 were $2.98 \pm 1.11,4.02 \pm 1.40$ and $1.85 \pm 0.26 \mathrm{ng} / \mathrm{g}$ for Groups 1,2 and 3 respectively; similar values for Day 17 were $2.73 \pm 0.45,2.52 \pm 0.41$ and $2.33 \pm 0.04 \mathrm{ng} / \mathrm{g}$. Testosterone synthesis was not significantly $(P>0.05)$ increased in any of the tissues incubated alone, or with added LH or arachidonic acid.

Oestradiol-17B. As expected, ovarian vein levels were several times higher $(P<0.05)$ than jugular vein concentrations. However, neither uterine vein nor ovarian arterial concentrations were higher $(P>0.05)$ than jugular vein concentrations in any of the 3 groups at Day 18 (Table 3). At Day 17, uterine vein concentrations were higher in Group 2 than in Group 1 animals $(P<0.05)$. Uterine vein concentrations of oestradiol were also higher $(P<0.05)$ at Day 17 than at Day 18 in Group 2 animals.

Table 3. Mean \pm s.e.m. oestradiol-17 $\beta$ concentrations in plasma and luteal tissue at Day 18 in pregnant and non-pregnant Holstein heifers

\begin{tabular}{|c|c|c|c|}
\hline & $\begin{array}{l}\text { Group } 1 \\
\text { (cyclic) }\end{array}$ & $\begin{array}{c}\text { Group } 2 \\
\text { (pregnant) }\end{array}$ & $\begin{array}{c}\text { Group } 3 \\
\text { (inseminated but } \\
\text { non-pregnant) }\end{array}$ \\
\hline No. of animals & 10 & 11 & 8 \\
\hline \multicolumn{4}{|l|}{ Plasma } \\
\hline Jugular vein $(\mathrm{pg} / \mathrm{ml})$ & $4.6 \pm 0.9$ & $5 \cdot 1 \pm 0.9$ & $3.8 \pm 0.4$ \\
\hline Ovarian vein $(\mathrm{pg} / \mathrm{ml})$ & $28 \cdot 9 \pm 9 \cdot 1^{*}$ & $35 \cdot 5 \pm 10 \cdot 9^{*}$ & $20 \cdot 5 \pm 6 \cdot 1^{*}$ \\
\hline Ovarian artery $(\mathrm{pg} / \mathrm{ml})$ & $29.4 \pm 15.9$ & $9 \cdot 3 \pm 3.6$ & $5.5 \pm 1.3$ \\
\hline Uterine vein $(\mathrm{pg} / \mathrm{ml})$ & $5.6 \pm 0.7$ & $10.7 \pm 3.7$ & $6.3 \pm 0.7$ \\
\hline \multicolumn{4}{|l|}{ Corpus luteum } \\
\hline Unincubated (ng/g) & $0.32 \pm 0.03$ & $0.50 \pm 0.14$ & $0.46 \pm 0.03 \dagger$ \\
\hline Incubated $(\mathrm{ng} / \mathrm{g})$ & $0.38 \pm 0.06$ & $0.43 \pm 0.05$ & $0.57 \pm 0.01$ \\
\hline Incubated with LH (ng/g) & $0.34 \pm 0.03$ & $0.43 \pm 0.05$ & $0.59 \pm 0.02$ \\
\hline $\begin{array}{l}\text { Incubated with arachidonic acid } \\
\text { (ng/g) }\end{array}$ & $0.38 \pm 0.08$ & $0.41 \pm 0.05$ & $0.54 \pm 0.01$ \\
\hline
\end{tabular}

* Values differ from those in the jugular vein, $P<0.05$.

$\dagger$ Value differs from that in Group $1, P<0.05$.

In all 3 groups, luteal tissues contained very small amounts of oestradiol $(0.32-0.50 \mathrm{ng} / \mathrm{g})$. The values for Group 3 were higher $(P<0.05)$ than in Group 1 at Days 17 and $18(P<0.05)$. Oestradiol synthesis was not stimulated in tissues from any of the animals by incubation with LH or arachidonic acid.

Prostaglandin $F$. At Day 18, PGF concentrations (Table 4) were higher in uterine vein plasma than in jugular vein, ovarian vein and ovarian arterial plasma in all 3 groups $(P<0.05)$. PGF concentrations in uterine venous plasma were higher $(P<0.06)$ in Group 1 than in Group 2 animals, but there were no differences in PGF concentrations in ovarian arterial or jugular venous plasma among the 3 groups, or in the endometrial or luteal tissue values. Luteal tissue from all 3 groups synthesized PGF in response to added arachidonic acid $(P<0.01)$. Data obtained for Day 17 animals were similar, except that luteal tissue from Group 3 animals contained less $(P<0.05)$ PGF than luteal tissue from either of the other 2 groups.

Arachidonic acid. Although concentrations of free arachidonic acid at Day 18 (Table 5) tended to be higher in plasma collected from all four sites from Group 1 animals than in plasma collected from Group 2 animals, none of these differences was statistically significant. Total arachidonic acid concentrations were extremely high $(3.0 \mathrm{mg} / \mathrm{g}$ tissue $)$ in luteal tissues from both pregnant and cyclic animals. The free acid concentration was higher $(P<0.05)$ in luteal tissues from cyclic than pregnant animals. Most of the arachidonic acid was in the phospholipid fraction and the data suggest that the increased free acid in luteal tissue of the cyclic animals could have 
Table 4. Mean \pm s.e.m. prostaglandin $F$ concentrations in plasma, luteal tissue and endometrium of Day 18 pregnant and non-pregnant Holstein heifers

\begin{tabular}{lccc}
\hline & $\begin{array}{c}\text { Group 1 } \\
\text { (cyclic) }\end{array}$ & $\begin{array}{c}\text { Group 2 } \\
\text { (pregnant) }\end{array}$ & $\begin{array}{c}\text { Group 3 } \\
\text { (inseminated but } \\
\text { non-pregnant) }\end{array}$ \\
\hline No. of animals & 10 & 10 & 8 \\
Plasma & $0.10 \pm 0.02$ & $0.09 \pm 0.01$ & $0.10 \pm 0.01$ \\
$\quad$ Jugular vein (ng/ml) & $0.18 \pm 0.05$ & $0.13 \pm 0.01$ & $0.12 \pm 0.01$ \\
Ovarian vein (ng/ml) & $0.15 \pm 0.03$ & $0.11 \pm 0.01$ & $0.15 \pm 0.03$ \\
Ovarian artery (ng/ml) & $0.65 \pm 0.16^{*} \dagger$ & $0.31 \pm 0.02^{*}$ & $0.58 \pm 0.20^{*}$ \\
$\quad$ Uterine vein (ng/ml) & $197.5 \pm 28.4$ & $257.9 \pm 34.4$ & $181.3 \pm 28.1$ \\
$\quad$ Endometrial tissue (ng/g) & & & \\
Corpus luteum & $27.7 \pm 5.5$ & $22.1 \pm 4.3$ & $23.4 \pm 2.6$ \\
$\quad$ Unincubated (ng/g) & $27.5 \pm 5.5$ & $22.5 \pm 4.5$ & $29.6 \pm 2.9$ \\
Incubated (ng/g) & $27.2 \pm 6.7$ & $22.1 \pm 4.7$ & $27.9 \pm 2.8$ \\
Incubated with LH (ng/g) & $73.4 \pm 6.5 \ddagger$ & $82.4 \pm 13.1 \pm$ & $83.6 \pm 12.2 \ddagger$ \\
Incubated with arachidonic acid & & & \\
$\quad$ (ng/g) & & & \\
\hline
\end{tabular}

* Values differ from those in the jugular vein, ovarian vein, and ovarian artery, $P<0.05$.

$\dagger$ Value differs from that in Group $2, P<0.06$.

$\ddagger$ Values different from those for $\mathrm{CL}$ tissues incubated alone and incubated with $\mathrm{LH}, P<0.01$.

Table 5. Arachidonic acid (AA) distribution in plasma, endometrium and corpora lutea of pregnant and non-pregnant Holstein heifers 18 days after oestrus

\begin{tabular}{llcr}
\hline & \multicolumn{1}{c}{ Fraction } & \multicolumn{1}{c}{$\begin{array}{c}\text { Group } 1 \\
\text { (cyclic) }\end{array}$} & \multicolumn{1}{c}{$\begin{array}{c}\text { Group 2 } \\
\text { (pregnant) }\end{array}$} \\
\hline No. of animals & & 9 & \multicolumn{1}{c}{10} \\
Jugular vein $(\mathrm{ng} / \mathrm{ml})$ & Free AA & $521.5 \pm 154.8$ & $273.4 \pm 25.2$ \\
Ovarian vein $(\mathrm{ng} / \mathrm{ml})$ & Free AA & $520.5 \pm 75.3$ & $372.2 \pm 38.1$ \\
Ovarian artery $(\mathrm{ng} / \mathrm{ml})$ & Free AA & $419.3 \pm 72.1$ & $329.3 \pm 32.6$ \\
Uterine vein $(\mathrm{ng} / \mathrm{ml})$ & Free AA & $422.4 \pm 77.7$ & $384.9 \pm 30.7$ \\
\hline Corpus luteum $(\mathrm{mg} / \mathrm{g})$ & Free AA & $0.66 \pm 0.16^{*}$ & $0.32 \pm 0.03$ \\
& Phospholipid & $1.88 \pm 0.09$ & $2.14 \pm 0.10$ \\
& Triglyceride & $0.35 \pm 0.12$ & $0.43 \pm 0.08$ \\
& Cholesterol ester & $0.15 \pm 0.04$ & $0.08 \pm 0.02$ \\
& Total AA & $3.04 \pm 0.19$ & $2.98 \pm 0.14$ \\
\hline Endometrium $(\mu \mathrm{gg} / \mathrm{g})$ & Free AA & $119.3 \pm 13.1$ & $125.6 \pm 12.2$ \\
& Phospholipid & $332.2 \pm 15.6$ & $355.3 \pm 17.7$ \\
& Triglyceride & $1.5 \pm 0.4$ & $1.2 \pm 0.3$ \\
& Cholesterol ester & $3.8 \pm 0.3$ & $3.5 \pm 0.4$ \\
& Total AA & $456.7 \pm 25.6$ & $485.6 \pm 26.6$ \\
\hline
\end{tabular}

Values are mean \pm s.e.m.

* Significantly different from value for Group $2, P<0.05$.

arisen from the phospholipid fraction. Very little arachidonic acid was in the cholesterol ester form. Endometrial tissues contained only about one-sixth as much arachidonic acid as did luteal tissue and most of the endometrial arachidonic acid was in the phospholipid fraction. No differences were found at Day 17 or 18 in the amounts of arachidonic acid in the other lipid fractions of luteal or endometrial tissues.

Lipoprotein lipase. These activities in luteal tissue at Day 18 were: $262 \pm 44,354 \pm 61$ and $382 \pm 50 \mathrm{nmol}$ free fatty acid/h/100 mg acetone powder for Groups 1,2 and 3, respectively ( $P$ $>0.05)$. The activities in luteal tissues removed at Day 17 were similar to those on Day 18 and did not differ from one another $(P>0.05)$. 


\section{Discussion}

The significant increase in plasma progesterone in pregnant, as compared to non-pregnant animals, during Days 10-18 (Text-fig. la) is in agreement with the recent data of Bulman \& Lamming (1978) and those of Henricks, Lamond, Hill \& Dickey (1975). The corpus luteum of the cow is not 'rescued' by a feto-placental luteotrophin, as it is in primates (Neill, Johansson \& Knobil, 1969). Rather, it appears to be stimulated by a factor or factors associated with the presence of an embryo at a time well before the onset of luteolysis in normal cyclic animals. The existence of a fetal luteotrophin is implied.

Shemesh, Milaguir, Sarah \& Ayalon (1979) found that bovine embryos (Days 13, 15 and 16) produced PGF and progesterone when cultured in vitro. Therefore, the higher progesterone concentration found in uterine vein than in jugular blood in the present study could be attributed to the embryo. However, uterine vein progesterone concentration was not significantly higher in pregnant than in cyclic animals, suggesting that the corpus luteum is the major contributor to the elevated peripheral progesterone levels in pregnant animals.

The results obtained with incubated luteal tissue (Table 1) were not unexpected; tissue from pregnant animals contained higher initial levels of progesterone and the tissue plus medium contained more progesterone when incubated alone, with $\mathrm{LH}$, or with arachidonic acid than did tissues from non-pregnant animals. However, luteal tissues of non-pregnant animals were still functional at Day 18, and these tissues responded to added $\mathrm{LH}$ with an increase in progesterone concentration equal to that of corpora lutea from pregnant animals. Corpora lutea from individual animals in which the jugular progesterone concentrations had clearly begun to decline were able to respond to $\mathrm{LH}$, and loss of responsiveness to $\mathrm{LH}$ is therefore not the first event in luteolysis. The responses of the luteal tissues from animals that were inseminated but not pregnant (Group 3) were intermediate, suggesting that these tissues had come under the influence of an embryo at an earlier stage of their development.

The increase in jugular oestradiol-17 $\beta$ in animals of all three groups between Days 2 and 5 (Text-fig. 1b) has been noted previously (Hansel \& Echternkamp, 1972). The higher oestradiol concentrations in jugular plasma of pregnant than of cyclic animals during Days 6-16 suggest that the embryo contributes, directly or indirectly, to plasma oestrogen levels. The data indicate that this increase may be due, in part, to synthesis of oestradiol by the embryo, since uterine venous plasma concentrations were higher $(P<0.05)$ in pregnant than in cyclic animals at Day 17. However, this difference was not significant $(P>0.05)$ at Day 18. Shemesh et al. (1979) noted oestradiol synthesis in vitro by some, but not all, Day 16 embryos. Collectively, these results suggest that the embryo may acquire the aromatizing enzyme system at about Day 17.

Although only single uterine vein and arterial blood samples could be obtained in this experiment, the data concerning plasma PGF concentrations (Table 4) give no support to the idea that the presence of an embryo causes luteal maintenance by depressing the concentration of PGF- $2 \alpha$ reaching the ipsilateral corpus luteum by way of the ovarian artery. Although uterine vein PGF concentrations were higher in cyclic animals than in pregnant animals at Day 18, ovarian arterial and jugular vein concentrations and endometrial PGF concentrations were similar. Since blood flow to the uterine horn containing the conceptus increases sharply between Days 14 and 18 of pregnancy (Ford, Chenault \& Echternkamp, 1979), the lower concentration of PGF found in uterine vein blood of pregnant than cyclic animals may represent a dilution effect.

The extremely high concentration of arachidonic acid in luteal tissue (Table 5) and the ability of luteal tissue to convert arachidonic acid to PGF (Table 3) suggest that products of the arachidonic acid cascade, produced within or accumulated by the corpus luteum, may play important regulatory roles. This suggestion is further supported by the finding that luteal tissue concentrations of free arachidonic acid were higher $(P<0.05)$ in Day 18 corpora lutea of cyclic than of pregnant animals. 
The data indicate that more of the free arachidonic acid in luteal tissue may arise from phospholipids than from triglycerides. Although there was a tendency toward higher concentrations of free arachidonic acid in ovarian arterial plasma of cyclic than of pregnant animals (Table 4), these differences were not statistically significant and the data therefore suggest that most of the free arachidonic acid in luteal tissue is of endogenous origin. However, the possibility that some of the free acid is contributed by the blood cannot be excluded. Shemesh \& Hansel (1975) reported specific binding of labelled arachidonic acid to luteal tissue. Interestingly, none of the luteal tissues in the present experiment synthesized PGF in vitro unless relatively large amounts of arachidonic acid were added, even though free arachidonic acid was present in tissues from both pregnant and cyclic animals.

We are grateful to Mr Raymond Saatman and Mr Jerry Sherman for technical and other assistance. The project was supported by funds provided by NIH Grant HD09870.

\section{References}

Abraham, G.E., Tulchinsky, D. \& Korenman, S.G. (1970) Chromatographic purification of estradiol$17 \beta$ for use in radio-ligand assay. Biochem. Medicine 3, 365-368.

Armstrong, D.T. \& Black, D.L. (1966) Influence of luteinizing hormone on corpus luteum metabolism and progesterone biosynthesis throughout the bovine estrous cycle. Endocrinology 78, 937-944.

Bulman, D.C. \& Lamming, G.E. (1978) Milk progesterone levels in relation to conception, repeat breeding and factors influencing acyclicity in dairy cows. J. Reprod. Fert. 54, 447-458.

Folch, J., Lees, M. \& Sloane-Stanley, G.H. (1957) A simple method for the isolation and purification of total lipids from animal tissues. J. biol. Chem. 226, 497-509.

Ford, S.P., Chenault, J.R. \& Echternkamp, S.E. (1979) Uterine blood flow of cows during the oestrous cycle and early pregnancy: effect of the conceptus on uterine blood supply. J. Reprod. Fert. 56, 53-62.

Fortune, J.E. \& Eppig, J.J. (1979) Effects of gonadotropins on steroid secretion by infantile and juvenile mouse ovaries in vitro. Endocrinology 104, 1834 1838.

Freeman, C.P. \& West, D. (1966) Complete separation of lipid classes on a single thin-layer plate. J. Lipid Res. 7, 324-327.

Hansel, W. (1971) Survival and gonadotrophin responsiveness of luteal cells in vitro. Acta endocr., Suppl. 153, 295-318.

Hansel, W. \& Echternkamp, S.E. (1972) Control of ovarian function in domestic animals. Am. Zoologist 12, 225-243.

Hansel, W. \& Fortune, J.E. (1977) The applications of ovulation control. In Control of Ovulation, pp. 237-263. Eds D. B. Crighton, N. B. Haynes, G. R. Foxcroft \& G. E. Lamming. Butterworths, London.
Henricks, D.M., Lamond, D.R., Hill, J.R. \& Dickey, J.F. (1975) Plasma progesterone concentrations before mating and in early pregnancy in the beef heifer. $J$. Anim. Sci. 33, 450-454.

Jaffe, B.M., Behrman, H.R. \& Parker, C.W. (1973) Radioimmunoassay measurement of prostaglandin $\mathrm{E}, \mathrm{A}$ and $\mathrm{F}$ in human plasma. J. clin. Invest. $\mathbf{5 2}$, $398-405$.

Kindahl, H., Edqvist, L.E., Bane, A. \& Granström, E. (1976) Blood levels of progesterone and 15-keto13,14-dihydro-prostaglandin $\mathrm{F}_{2} \alpha$ during the normal oestrous cycle and early pregnancy in heifers. Acta endocr., Copenh. 82, 134-149.

Metcalfe, L.D., Schmitz, A.A. \& Pelka, J.R. (1966) Rapid preparation of fatty acid esters from lipids for gas chromatographic analysis. Analyt. Chem. 38, 514-515.

Neill, J.D., Johansson, E.D.B. \& Knobil, E. (1969) Failure of hysterectomy to influence the normal pattern of cyclic progesterone secretion in the Rhesus monkey. Endocrinology 84, 464-465.

Niswender, G.D., Reichert, L.E., Midgley, A.R. \& Nalbandov, A.V. (1969) Radioimmunoassay for bovine and ovine luteinizing hormone. Endocrinology 84, 1166-1173.

Shemesh, M. \& Hansel, W. (1975) Stimulation of prostaglandin synthesis in bovine ovarian tissues by arachidonic acid and luteinizing hormone. Biol. Reprod. 13, 448-452.

Shemesh, M., Bensadoun, A. \& Hansel, W. (1976) Lipoprotein lipase activity in the bovine corpus luteum during the estrous cycle and early pregnancy. Proc. Soc. exp. Biol. Med. 151, 667-669.

Shemesh, M., Milaguir, F., Sarah, L. \& Ayalon, N. (1979) Steroidogenesis and prostaglandin synthesis by cultured bovine blastocysts. J. Reprod. Fert. 56, 181-185.

Received 17 December 1979 